Columbia Law School

Scholarship Archive

1994

Considering Zenger. Partisan Politics and the Legal Profession in Provincial New York

\title{
Eben Moglen
}

Columbia Law School, moglen@law.columbia.edu

Follow this and additional works at: https://scholarship.law.columbia.edu/faculty_scholarship

Part of the Law and Politics Commons, and the Legal History Commons

\section{Recommended Citation}

Eben Moglen, Considering Zenger: Partisan Politics and the Legal Profession in Provincial New York, 94 Colum. L. ReV. 1485 (1994).

Available at: https://scholarship.law.columbia.edu/faculty_scholarship/152

This Article is brought to you for free and open access by the Faculty Publications at Scholarship Archive. It has been accepted for inclusion in Faculty Scholarship by an authorized administrator of Scholarship Archive. For more information, please contact scholarshiparchive@law.columbia.edu. 


\section{COLUMBIA LAW REVIEW}

VOL. 94

JUNE 1994

NO. 5

\section{CONSIDERING ZENGER: PARTISAN POLITICS AND THE LEGAL PROFESSION IN PROVINCIAL NEW YORK}

\section{Eben Moglen*}

\section{The Story of a Gold Box}

History is the narration of the past, and not all valuable history is true. When William Smith, Jr. first wrote his much-admired and widelydistributed History of the Province of New-York, in 1756, he ended his narration twenty-four years before his own time, with the arrival of Governor William Cosby in New York on August 1, 1732. In justification of his abrupt termination at this particular point, Smith wrote:

The history of our publick transactions, from this period, to the present time, is full of important and entertaining events, which I leave others to relate. A very near relation to the authour had so great a concern in the publick controversies with Colonel Cosby, that the history of those times will be better received from a more disinterested pen. To suppress truth on the one hand, or exaggerate it, on the other, are both inexcusable faults, and perhaps it would be difficult for me to avoid those extremes. ${ }^{1}$

In his twenty-ninth year, already an important and rising member of the New York Bar, Smith was unwilling to describe the role played by his father, still living and soon-in 1760 - to refuse the Chief Justiceship of the Province, in the political turmoil of the Cosby Administration. To modern readers, trained to view those times through the lens of a single famous event, William Smith, Jr. begged off from telling the story of the Zenger Case.

But beginning in 1777, under genteel house arrest at Livingston Manor for failure to take a patriot's oath, during the crucial years that saw his ultimate dedication to the Loyalist cause, Smith returned to the history of the province. His father had died in 1769, and amidst the wreck of the entire system around which his life-professional, literary, and social-had been built, Smith, while keeping the most detailed diaries of the military events of the war, cast his mind back. The events whose violence of color had seemed so threatening when he was young, must, as he

* Associate Professor of Law, Columbia Law School. B.A. 1980, Swarthmore College; M. Phil. 1985, J.D. 1985, Ph.D. (History) 1993, Yale University. I wish to thank Barbara Black, Vincent Blasi, Pamela S. Karlan, William E. Nelson and John Reid for their contributions to this project.

1. 1 William Smith, Jr., The History of the Province of New-York 195-96 (Michael Kammen ed., Belknap Press 1972) (1757). 
wrote, have seemed pale in comparison to the surrounding evidences of what the popular song of the day called "The World Turned UpsideDown."

So-without all the notes and documents he had painstakingly carried from his house at Number 5 Broadway to his country retreat at Haverstraw-in his neat but increasingly minuscule handwriting, Smith told the story of Governor Cosby's grasping and corrupt administration, of the plots of Francis Harison-with or without the Governor's knowledge- to have his father and James Alexander hanged, of the fight over the salary of Rip Van Dam and the legality of the Exchequer Court, of the printer John Peter Zenger. He wrote of the young and arrogant Chief Justice James DeLancey's sudden disbarment of Zenger's defense counsel, James Alexander and William Smith, Sr. He described the mediocre placeman, John Chambers, appointed to defend Zenger with faint zeal, and the sudden, dramatic appearance of Andrew Hamilton of Philadelphia, secretly retained to do as he did-stalwartly confronting the Bench, seducing the jury, striking the critical tactical blow in the war to the death between the Governor and the lawyers who were the center of the Morrisite opposition. He told of the outburst of huzzas that greeted Zenger's acquittal on August 4, 1735, and the night of celebration that followed. And, as a fitting and dramatic climax, the demonstration on the Hudson River waterfront the following morning, when, as Hamilton departed for Philadelphia,

he entered the barge under a salute of cannon, and the Corporation presented him with the freedom of the city in a gold box, on which its arms were engraved, encircled with the words, "Demersae leges-time facta libertas-haec tandem emergunt;" in a flying garter within, "Non nummis, virtute paratur," and on the other front, "Ita cuique eveniat ut de respublica meruit."

No historian of the Zenger episode could be better placed to tell its story. As a boy of seven, Smith himself was a partial witness to the events-no doubt it formed the basis of much talk in his household, as it did in the other houses of the city whom it much less intimately concerned. His father-who was also Smith's primary instructor in the lawplayed a critical role. James Alexander, who more than anyone else was the mastermind of the long and dangerous game in which the Zenger trial was but a minor component, became the younger Smith's trusted friend, advisor, and sometime adversary. It was Alexander's library of his-

2. Cited in Christopher Hill, The World Turned Upside Down: Radical Ideas During the English Revolution 307 (1972).

3. $2 \mathrm{~W}$. Smith, Jr., supra note 1, at 20-21. The manuscript of Smith's continuation of his History is in the collection of his papers at the New York Public Library. It was published, badly edited by his son, in Quebec in 1824, and reconstructed by the brilliant editorial labor of Michael Kammen, whose 1972 edition is cited here. The Latin mottoes, discussed below, might roughly be translated as "Though the laws are sunk and liberty trembles at the deed, yet shall they rise again," "Not by money, but by virtue gained," and "Thus let each receive what he has deserved of the republic." 
torical manuscripts and capacious recollection that provided much of the material from which the first volume of Smith's History was written; only his death in the spring of 1756, as Smith lamented in his Preface, prevented him from having a larger editorial hand in that project. ${ }^{4}$ Yet, for all the authority of his special relation to the sources, Smith's account of the Zenger imbroglio was not the basis of the history written about Zenger from the work of George Bancroft until well into our own time. These historians ${ }^{5}$ treated the trial and acquittal of John Peter Zenger as a crucial moment in the history of freedom of speech. For more than a century, the Zenger Case was an emblem-the moment when the jury's general verdict and the defense of truth began the destruction of seditious libel as an ancillary doctrine for the political control of the press. But Smith's history was no support for this interpretation, for Smith knew it wasn't so. Smith knew what the best of twentieth-century scholarship rediscovered, that the trial of John Peter Zenger represented the triumph of an artful advocate over, rather than through, the law. ${ }^{6}$ Far from bringing about changes in doctrine anywhere, what Smith knew well enough to call the "fraudful dexterity of the orator" left the development of the law to proceed, as Stanley Katz pointed out in 1963, "as if Peter Zenger had never existed." 8

For the contemporary historians who have recovered Smith's insight, the real significance of the Zenger episode lies in its foreshadowing:

4. See $1 \mathrm{~W}$. Smith, Jr., supra note 1 , at 5-6.

5. See, e.g., 2 George Bancroft, History of the United States of America from the Discovery of the Continent 254-55 (New York, D. Appleton \& Co. 1886); Charles A. Beard et al., The Beards' New Basic History of the United States 86 (1960) (crediting Zenger trial with making "freedom of the press a cherished privilege in the American colonies"); Richard N. Current et al., American History: A Survey 52 (1961) (describing Zenger as "a verdict which meant a long stride toward freedom of the press"); 2 John Fiske, The Dutch and Quaker Colonies in America 244 (1903) ("Hamilton may be said to have conducted the case according to the law of the future, and thus to have helped to make that law."); 3 James Grahame, History of the United States of North America: From the Plantation of the British Colonies Till Their Assumption of National Independence 234-37 (Boston, Charles C. Little and James Brown 1845) (Zenger established the "inviolable right of freemen to publish to their fellow-citizens every truth that concerned the general weal, and every grievance by which their common birthright of liberty was impaired or invaded"); 2 Richard Hildreth, History of the United States of America 360 (New York, Harper \& Bros. 1856) ("The freedom of the colonial press was vindicated by the Zenger trial."); Paul Finkelman, The Zenger Case: Prototype of a Political Trial, in American Political Trials 21, 21-42 (Michal R. Belknap ed., 1981) ("For traditional American historians the trial of John Peter Zenger has always represented a great victory for liberty and freedom of the press."), id. at 22.

6. See Leonard W. Levy, Freedom of Speech and Press in Early American History: Legacy of Suppression 126, 130 (1963); Stanley N. Katz, Introduction, [hereinafter Katz] in James Alexander's Brief Narrative of the Case and Trial of John Peter Zenger, Printer of the New York Weekly Journal 1-2, 34-35 (Stanley N. Katz ed., 2d ed. 1963) [hereinafter Brief Narrative].

7. 2 W. Smith, Jr., supra note 1 , at 20 .

8. Katz, supra note 6 , at 2 . 
[V]iewed in its full contemporary context, it reveals not the conclusion but the origins and sources of change: it allows us to see in dramatic detail the nature of the forces developing in the early eighteenth century which would end, two generations later, in the transformation of both politics and law. ${ }^{9}$

In one sense, this is certainly the meaning of the Zenger Case, as Stanley Katz has brilliantly shown. But it cannot be the meaning of the story of the gold box. Plainly, the people gathered at the Hudson River ferry landing on that August morning in 1735 were not celebrating the forces that would end, two generations later, in revolutionary changes in politics and law. Nor was that the meaning of the story for William Smith, Jr., for whom the changes in politics and law of which Katz wrote were most unwelcome, and therefore no cause for celebration.

Thus, to go along with the myth about the Zenger Case and freedom of speech, and the true story of the Zenger Case in its relation to the future, there must be another story, resonating in the space between 1735 and 1777, centered on the emblem of the gold box and its Ciceronian mottoes. Viewed in its full contemporary context, it is the story of partisan politics as a bloodsport, with death and destitution as the consequences of failure. It is a story of New York's lawyers, a small group of men separated by political animosity but joined in professional interest, at a critical moment in the constitutional history of the province. It is about how professional virtue triumphed over money, but not in the person of Andrew Hamilton. The episode of which the Zenger case was a part shows us much about the development of the legal profession in New York, and its role in the political and constitutional convulsions that ended the provincial period. In it we can trace the progress and consequences of the professionalization of the Bar in New York. That professionalization, which made the Bar an independent center of political power resistant to executive and judicial control, significantly affected the later political history of British North America. ${ }^{10}$ The story of the gold box presented to Andrew Hamilton on the morning after Zenger's acquittal has much to teach us about the history of the law in one small corner of the first British Empire, but there is one more thing to be said before setting out: The presentation didn't really happen.

\section{Id.}

10. Some recent nonhistorical scholarship has also used the existing accounts of the Zenger trial to demonstrate the process of professionalization, or the mechanisms by which defense counsel traditionally fought political influence over the criminal trial process. See Susan P. Koniak, The Law Between the Bar and the State, 70 N.C. L. Rev. 1389, 1447-60 (1992); Bruce J. Winick, Forfeiture of Attorneys' Fees under RICO and CCE and the Right to Counsel of Choice: The Constitutional Dilemma and How to Avoid It, 43 U. Miami L. Rev. 765, 790-97 (1989). Winick-rather improbably, in light of the facts as I have set them out below-also would have us believe that the Zenger trial "stands as a vindication of the right to appear through chosen counsel, rather than one appointed by the court." Id. at 791. 


\section{New York Courts ANd the Politics of Party}

The Zenger episode was part of a larger sequence of events in the legal and political history of the province, which throws into high relief the relation between legal institutions and partisan conflict in that particularly fractious polity. The labyrinthine and occasionally violent divisions in New York were famous both to contemporary observers and later historians; not for nothing is the most perceptive history of New York's political life during the provincial period entitled A Factious People. ${ }^{11}$ But one aspect of that complex history, taken for granted by contemporaries and obscured from the view of most historians, was the relationship between the courts and the geometry of political contest. Partisan conflict in New York was often waged not just in, but apparently over, the courts; the terms of their existence, by virtue of the contingencies of New York's constitutional history, provided a fertile field for confrontation between the legislative and executive elements in the provincial government. When partisan conflict over the courts joined with the other distinctive element of New York's political life-the constant mutual suspicion in partisan circles that the opposition was intending not just political victory, but the economic and physical destruction of its adversaries - the background to the Zenger story becomes more comprehensible. The roots of both these elements - the permanent casus belli and the real or imagined ferocity of political division-lie in the decade of the $1680 \mathrm{~s}$. So it is there, in the infancy of the oldest participants in the Zenger controversy, that the story really began.

James Stuart, Duke of York and later King James II, Defender of One or Another Christian Faith, was evidently no friend of elected legislative assemblies. During his long tenure as the Proprietor of New York-from 1664 until he fled the advancing troops of the Prince of Orange in December 1688-James only once, for a brief two-year period, allowed the New Yorkers to choose members of a provincial assembly. The first such election was held in New York in September 1683; the resulting legislature convened in October of that year. Though it sat for only three weeks, the new Assembly managed to produce a burst of important legislation, including a judiciary act establishing a new system of courts for the province. ${ }^{12}$ In addition to the formalization of local justice, the Assembly took upon itself the redefinition of the provincial high court, the Court of Assizes. Though the Assembly said it was to be "esteemed" as the

11. See Patricia U. Bonomi, A Factious People: Politics and Society in Colonial New York (1971).

12. See "An Act to settle Courts of Justice," Nov. 1, 1683, reprinted in 1 The Colonial Laws of New York from the Year 1664 to the Revolution 125-28 (Albany, J.B. Lyon 1894) [hereinafter N.Y. Colonial Laws]. For a more detailed discussion of the events of the $1680 \mathrm{~s}$ in their relation to the beginnings of the New York legal system, upon which I have drawn for present purposes, see Eben Moglen, Settling the Law: Legal Development in New York, 1664-1776, at 45-60 (1993) (unpublished Ph.D. dissertation, Yale University) (on file with the Columbia Law Review). 
Supreme Court of the province, it was to have only an equitable jurisdiction. From the highest common-law courts of the Assembly's creation, the Courts of Oyer and Terminer, appeal was to run directly to the King in Council. The preceding regime of a centralized court, led by the Governor, doing all the major legal business of the province, was replaced by legislative mandate. For the first time, but not the last, New York's legislature wanted to determine the structure of the judiciary.

James took the constitutional opportunity presented by his accession to the throne in 1685 to restructure the government of New York without even the ghost of a representative assembly. Justice was done in New York according to the outlines of the 1683 Act until New York was joined to the Dominion of New England in April 1688, at which point, at least nominally, the local courts of New York were replaced by the judicial system of the Dominion.

But the Dominion's government collapsed, beginning in April 1689, with an uprising in Boston staged upon confirmation of the downfall of the Stuart monarchy at home. Within weeks, government in New York had collapsed as well, and the vacuum of authority was filled by an immigrant German merchant and militia captain, a member of the Dutch Reformed Church, named Jacob Leisler, who claimed to be governing the province in the interest of William and Mary, pending definitive word of the new sovereigns' pleasure. But the foundations of Leisler's regime were never secure; both on Long Island and at Albany there was resistance to his pretensions to authority, and in New York City Leisler resorted to increasingly repressive measures directed at his opposition, which was led by some of the most important members of the AngloDutch merchant community. By January 1690/91, some of New York's leading citizens were in jail, their estates had been confiscated or lay under threat of confiscation, and the soi-disant Governor seemed to some to be taking leave of reality. When Captain Richard Ingoldsby, the military representative of the newly-appointed Royal Governor demanded Leisler's surrender, Leisler was foolish enough to refuse, and an armed stand-off resulted, ending only with the arrival of the new Governor, Henry Sloughter, in March 1691. Sloughter's ire was deliberately inflamed by the local grandees who had suffered at Leisler's hands; by the end of May 1691 Leisler and his son-in-law had been executed after trial on treason charges, and confiscations and other retributive measures against his supporters were well under way. ${ }^{13}$

13. Leisler's Rebellion has not lacked for historical treatment; fine general accounts of events and their local significance can be found in a number of works. See, e.g., Jerome R. Reich, Leisler's Rebellion: A Study of Democracy in New York, 1664-1720, at 55-126 (1953); Robert C. Ritchie, The Duke's Province: A Study of New York Politics and Society, 1664-1691, at 198-231 (1977). For a superb account of the events in New York in relation to the occurrences elsewhere in British North America in 1689, see David S. Lovejoy, The Glorious Revolution in America 235-364 (1972). 
The effects of the events surrounding what came to be called "Leisler's Rebellion" on the tone of political life in provincial New York cannot be overstated. The savage anti-Leislerian backlash of 1691 established not only a polarized political environment in the Province, but one in which judicial expropriation and execution of one's opponents was the stake in the lottery for political power. What anti-Leislerians did under Sloughter and his successor, Benjamin Fletcher, survivors of the Leislerian party attempted to do again under the government of Richard Coote, Earl of Bellomont. Eventually Nicholas Bayard, one of the leaders of the anti-Leislerian party since his imprisonment by Leisler in 1690 , was-in retribution for the events of 1691-convicted of treason on inflated charges and sentenced to death in 1702 , a verdict later reversed by the Privy Council.14 Even after the first generation of antagonists passed from the scene, and New York began to enjoy a less brutally partisan political environment-as it did under the long administration of Governor Robert Hunter, from 1710 to 1719 -the political history of the Province remained an incendiary force in the political culture, reminding everyone that partisan contest turned easily in the direction of judicially sanctioned murder and confiscation, preparing the mind for plots and conspiracies. The echoes of Leisler's rebellion and its sequels never died away; ${ }^{15}$ they played a major role in the events of the 1730 s of which Zenger's trial was a minor intermediate episode.

In the immediate aftermath of the Leisler fiasco, as William and Mary's government was being organized, elections to a new representative assembly occurred, under the arrangements that would thereafter prevail in New York until independence. The new Assembly, meeting in the spring of 1691, reenacted some of the basic legislation of the Proprietary Assembly, and drafted a new Judiciary Act, again establishing the fundamental courts of the Province, though on a basis different from that of 1683. The new legislation, drafted by the Assembly's speaker, James Graham, who had been Attorney-General of the Dominion, basically domesticated the Dominion's judicial structure for the province, providing at the apex of the system for a Supreme Court, with appointed judges not

14. See Trial of Colonel Nicholas Bayard, in the Province of New York, for HighTreason: 14 William III (1702), in 14 Complete Collection of State Trials and Proceedings for High Treason and other Crimes and Misdemeanors 471 (T.B. Howell ed., London, T.C. Hansard 1816).

15. William Smith, Jr., as an historian, was all too conscious of the endless echoes of the Leisler drama. After the publication of the first volume of his History, in 1757, one of his first correspondents was Leisler's granddaughter, who complained vehemently of the slander on his memory that she believed Smith had perpetrated. Smith, who took quite an even-handed view of the episode itself, responded with a letter, a draft of which survives, in which he protested his "good opinion of [Leisler's] Heart and Designs in setting up for the Prince of Orange and if there was not the greatest Prudence used by that Party it must be ascribed in a great degree to the Confusion \& Heat of the Times." Letter from William Smith, Jr. to Mrs. Farmer 1 (July 7, 1759), William Smith Papers, Box 3, Lot 208, Item 3 (New York Public Library, Rare Books and Manuscripts Division). 
to include the Governor, whose jurisdiction was to include "all pleas, Civill Criminall, and Mixt, as fully \& amply to all Intents \& purposes whatsoever, as the Courts of King's Bench, Comon Pleas, \& Exchequer within their Majestyes Kingdome of England, have or ought to have."16 The Judiciary Act of 1691 was a crucial item in the provincial constitution of New York-the judicial institutions its words created were the bone and sinew of the legal system throughout the eighteenth century. ${ }^{17}$

But the Act was not law. The official constitutional position of the Crown-whether held by a representative of the House of Stuart, Orange, or Hanover - was that courts could not be created in the Empire by act of the local legislatures. Only the Governors, acting as delegates of the Crown itself, could establish courts, and all Royal Instructions issued to New York's Governors, including especially those issued to Henry Sloughter, said so explicitly. Officially, the Act of 1691 had not the approval of the Crown, and the Supreme Court of New York, and all its acts, judgments, rules, and titles to real estate and other property secured by its decisions, rested upon Ordinances issued by the Governor himself. To this position, in turn, no Assembly would be prepared explicitly to accede. Tacit acceptance of each side's position that it alone could found the courts was the ordinary course, but beneath the surface of the proprieties there lay the constitutional abyss. If the contingencies of ordinary politics led one side or the other to declare its position in terms that would force the issue, the legitimacy of the courts would be the first casualty of constitutional conflict.

This calm, pregnant with the possibility of calamity, existed a fortiori with respect to equity. The 1691 Act provided for no Chancery jurisdiction, except insofar as the Exchequer jurisdiction of the Supreme Court may have implied one. ${ }^{18}$ Beginning in 1711, when Governor Hunter revived the Chancery jurisdiction (originally created by ordinance in 1702 but entirely dormant) with himself as Chancellor, and appointed officers of the court, the employment of equitable jurisdiction in the Province always threatened to raise the grand problem. The Assembly responded to Hunter immediately with a denial of the right to erect courts without

16. "An Act for the Establishing Courts of Judicature for the Ease and benefitt of each respective Citty Town and County within this Province," May 6, 1691, reprinted in 1 N.Y. Colonial Laws, supra note 12, at 226, 229.

17. For the standard published account of the Judiciary Act of 1691 and the institutions it created, see Note, Law in Colonial New York: The Legal System of 1691, 80 Harv. L. Rev. 1757 (1967); see also Moglen, supra note 12, at 52-60 (describing the Judiciary Act of 1691 as bringing "to a close the first period in the legal settlement of New York ${ }^{n}$ ).

18. Traditionally in England, the Court of Exchequer had both a common-law and an equitable jurisdiction, often called, respectively, the "Latin side" and the "English side" after the language of record. The broadest construction of the language of the 1691 Act would have taken the grant of jurisdiction to the Supreme Court to imply an equitable jurisdiction parallel to that found in English Exchequer. In the strictest original sense that would have extended to equitable claims arising in the course of litigation over the revenue of the Crown. 
the Assembly's concurrence, and Hunter in turn sought a further explicit order from the Board of Trade, which most often acted as the voice of the Privy Council and the King in matters of colonial administration. Thereafter, though equitable jurisdiction was extensively employed by so active and popular a governor as William Burnet, ${ }^{19}$ the possibility that political resistance would locate in and then attack the legitimacy of the court and, more importantly, its past decisions, was never entirely absent. ${ }^{20}$

Thus, the closing decades of the seventeenth century bequeathed to the Province's politicians and lawyers of the eighteenth century two apparently unrelated conditions: a political environment sometimes actively and always potentially brutal in the stakes for which the game of power was played, and a latent constitutional controversy whose terms threatened the immediate destabilization, or as I have elsewhere called it, "unsettlement," of the legal system. ${ }^{21}$ Beginning in the fall of 1732, the arrogance and covetousness of Colonel William Cosby, all unknowing, laid the fire to those fuses. The resulting explosion-more accurately, a cataclysm barely averted-had, as one of its subsidiary features, what we know as the Zenger Case.

\section{Unsettling the Courts: The Affair of the Governor's Salary}

The baggage of Governor Cosby, upon his arrival on August 1, 1732, contained two predominant and often-associated guises for an officeholder of his time and place: high socio-political connections at home, and a desperate need for money. ${ }^{22}$ Brother-in-law to the Earl of Halifax, Cosby had already acquired a reputation for conduct on the windy side of

19. As William Smith, Jr. said of Burnet—the son of the revered Bishop- "The Office of Chancellor was his delight [and] [h] e made a tolerable figure in the exercise of it, tho' he was no lawyer." $1 \mathrm{~W}$. Smith, Jr., supra note 1, at 165 . The order books and much supporting material from Burnet's Administration as Chancellor have survived, and when edited for publication will cast much light both on the politics of equity in New York during the apparently quiet period of the 1720 s, and on important doctrinal questions. The editorial work presents substantial problems of its own, however, which I hope to resolve in due course.

20. The story of opposition to equitable jurisdiction in New York through the end of the Cosby Administration has been told by Stanley N. Katz, The Politics of Law in Colonial America: Controversies Over Chancery Courts and Equity Law in the Eighteenth Century, in Law in American History 257, 272-82 (Donald Fleming \& Bernard Bailyn eds., 1971). Katz's comparative perspective shows the relation between these events and those in other colonies extremely well, but the same perspective makes it difficult for him simultaneously to expose the internal relationship between this and other constitutional problems in New York itself.

21. See Moglen, supra note 12 , at $252,257$.

22. Beside the contemporary histories of the Cosby Administration written by William Smith, Jr., and Cadwallader Colden, see Cadwallader Colden, History of Governor William Cosby's Administration and of Lieutenant-Governor George Clarke's Administration through 1737, in 9 Letters and Papers of Cadwallader Colden 283-355 (68 Collections of the N.Y. Hist. Soc'y 1935), the single most valuable account is Stanley N. Katz, Newcastle's New York: Anglo-American Politics, 1732-1753, at 61-132 (1968). 
legal administration where it was in his pecuniary interest. As Governor of Minorca in 1718, he had involved himself in some rather shady manipulations to justify the seizure of the goods of a Catalan merchant with whose Government His Majesty was not at the time at war. Cosby, who had a substantial financial interest in the seizure, was reputed to have denied the right of appeal and secreted or destroyed documents to prevent the reversal of his decision. At least, that's what the New Yorkers thought of their new Governor. ${ }^{23}$

Cosby's predecessor as Governor, John Montgomerie, served from 1728 through his death in June 1731. A professional soldier turned courtier-Groom of the Bedchamber to George II while Prince of Wales-Montgomerie had, according to the estimate of William Smith, Jr., "neither strength nor acuteness of parts, and was but little acquainted with any kind of literature." 24 Montgomerie, perhaps out of awareness of his own limitations, resolved the controversy over the Governor's equity jurisdiction that had heated up at the end of Burnet's tenure by refusing to convene his court at any time, even when directly ordered to do so by Whitehall. Never having met Calvin Coolidge, and necessarily not knowing Dorothy Parker's joke about the inability to tell whether Silent Cal was dead or alive, William Smith, Jr. could only record in description of Montgomerie that "he devoted himself so much to his ease, that he has scarce left us any thing to perpetuate the remembrance of his time."25 But Montgomerie had left one thing behind: the right to draw his salary. As it turned out, that was enough to bring the Province to the boiling point.

The British Imperial patronage system in the epoch of the Duke of Newcastle, like the mills of God, ground both very slowly and exceedingly small. By the time news of a vacancy could cross the Atlantic, be digested, and eventuate in the selection of a successor, who then took his time arriving on post, the interim holder of the office might well have cashed a few warrants. In New York, the interim Governor was the most senior member of the Council, ${ }^{26}$ and upon the death of Governor Montgomerie this was Rip Van Dam, a distinguished Anglo-Dutch merchant, seventy-

23. For the story as it entered the grapevine of New York politics, the best witness is William Smith, Jr., who made it the mise-en-scene of the second volume of his History. See 2 W. Smith, Jr., supra note 1 , at 3.

24. 1 id. at 187 .

25. 1 id. at 188. For Montgomerie's inspired solution to the Chancery dilemma, and the Board of Trade's unsympathetic reception of his genius, see Letter from $J$. Montgomerie, Governor of New York, to the Lords of Trade (Nov. 30, 1728), in 5 Documents Relating to the Colonial History of the State of New York 871, 874-75 (E.B. O'Callaghan ed., 1855) [hereinafter N.Y. Colonial Documents]; Letter from the Lords of Trade to Governor J. Montgomerie (May 28, 1729), in 5 N.Y. Colonial Documents, supra, at 876-77. Whitehall's concern was that failure to employ the Chancery jurisdiction left the King without any coercive measures for the collection of quitrents.

26. Like almost all matters of any constitutional significance in New York, this rule was the outcome of a violent controversy in the last years of the seventeenth century. The position stated in the text was originally the contention of William "Tangier" Smith (no 
two years of age, and a member of the Council for almost thirty years. Van Dam presided over the Province for exactly thirteen months. Such remuneration as he drew during the period would not have been of the greatest moment to him-though he was not so unimpressionable as to avoid putting to the Council the question whether he should draw the whole of the salary or just half, which they predictably decided in favor of the whole-until Cosby stretched out his hand for it.

Within his first few months as Governor-and only after requesting a large cash gratuity from the Assembly for lobbying services allegedly provided at home-Cosby presented the Crown's order for the division of the interim salary between himself and Van Dam. Van Dam, upon reading the order, rejoined that he would be happy to render half of his draw, which had been $£ 1,975.7 .10$, if Cosby would make over half the perquisites paid to him in London at the same period, which Van Dam claimed were $£ 6,407.18 .10$. Unwilling to forego his thousand pounds, and certainly not the fellow to lose an opportunity to exert influence over the courts, Cosby brought suit. But he faced some difficulties. If he sued in the Supreme Court, he would face a local jury, which seemed unlikely to favor his position in preference to Van Dam's. Not even his own effrontery was sufficient to the task of reviving the dormant equity jurisdiction, however much that would please Whitehall, in order to bring before himself his own claim to $£ 1,000$. So Cosby, more fertile in animosity than wisdom, chose to issue an ordinance for a sitting of the Supreme Court as Court of Exchequer, in which he could proceed to be heard on his own claim as the Court's first and only case, without benefit of jury.

The Bench would not be entirely sympathetic. To be sure, Frederick Philipse was part of a clan allied with the Governor, and entirely predictable. The young James DeLancey, son of one of the richest and most influential men of the Province, educated at Cambridge and the Inner Temple, not yet thirty and already a Justice of the Supreme Court, was another staunch ally. But even with the weight of numbers for him, Cosby faced his nemesis in the center of the Bench. Chief Justice Lewis Morris, Jr. was the greatest political figure of his time, and already the center of the opposition to Cosby's Administration. First elected to the Assembly in 1707, Chief Justice from 1715, and Councilor after 1721, Morris had been the closest political advisor of Robert Hunter and William Burnet. Dropped from the Council by Montgomerie, Morris had consolidated his position as the center of anti-Executive political machination even before Cosby's arrival, and the Chief Justiceship was his base of power. Morris was old in the ways of provincial politics before Cosby was even thought of, and as William Smith, Jr. was to say of him, "[t]ho' he was indolent in the management of his private affairs, yet, thro' the love of power, he was always busy in matters of a political nature, and no man

relative of the historian), who had defended it to the point of incipient civil war on the death of Governor Bellomont. See $1 \mathrm{~W}$. Smith, Jr., supra note 1, at 110-11. 
in the colony equaled him in the knowledge of the law and the arts of intrigue."27

What happened next was a foreseeable variation on the old theme of objection to prerogative courts. On April 9, 1733, Van Dam's counsel, James Alexander and William Smith, Sr.-two of the most prominent members of the small provincial Bar-presented a series of exceptions to the commissions of the judges. Though they made a number of other points (that the two senior judges had not been recommissioned upon the death of George I, that the appointments were not with the advice and consent of the Council, etc.), the central claim was that the commissions were invalid in authorizing them to exercise an equitable jurisdiction in Exchequer, there being no legislative authorization for such a jurisdiction. In context, this was not a particularly perilous strategy for Smith and Alexander. Two of the Morrisite lawyers of the Province were arguing to their own leader in his role as Chief Justice that he should refuse to hear the politically inflammatory lawsuit of the Governor against one of the Morrisite allies on the Council. Predictably, Morris delivered a prepared opinion upholding the exception to the equitable jurisdiction. On the 10th of April, James DeLancey offered his opinion contra, and at the opening of the Trinity Term Philipse gave his vote to the same effect. Morris withdrew from the Bench after delivering a viva voce attack upon the opinions of his colleagues, and took the aggressive step of publishing his own opinion on the absence of jurisdiction.

So far, the constitutional abyss had not yawned very wide. The partisan squabble in the Exchequer Court (if that's what it was) had brought the institution to a standstill, but as an institution it wasn't doing anything anyway. Morris, Smith, Alexander, and Van Dam had cooperated to embarrass the Governor, and could go a little further by bringing an action on Van Dam's behalf against him in the Supreme Court, but the Governor was not amenable to process there, and so the whole affray seemed likely to sputter out. And then, on August 21, Cosby suspended Morris as Chief Justice, and two days later replaced him with James DeLancey, who was thus able to begin his thirty-first year as Chief Justice of His Majesty's Province of New York.

Perhaps Cosby saw this stroke as a checkmate to the Morrisites; perhaps in eternity the shade of William Cosby will inquire of the shade of Richard Nixon what he was thinking of on the Saturday evening when he fired Archibald Cox. At any rate, the effort miscarried. In retrospect, as William Smith, Jr. saw it, "this unguarded measure . . . added fresh oil to the flame, already spread through the colony, and excited the fears of the multitude."28 The effect was to present the Morrisite party with no choice but to wage the campaign against the Governor in the sphere of populist politics, and the unlikely metamorphosis of Lewis Morris into a 
"Leader of the People" began. Morris and his son were returned to the Assembly from Westchester County in the fall elections despite jugglery by the returning officer, Cosby's appointed Sheriff, who attempted to disqualify Morrisite Quaker voters by requiring oaths rather than affirmations of qualification to vote. This whiff of religious bigotry was particularly obnoxious in the New York context, and the Cosbyites only increased the Morrisite momentum. Attention now shifted to the election of a Morrisite majority to the New York City Common Council at the elections in September of 1734. For the purpose of waging a more effective populist campaign in the city, the Morrisites, led by James Alexander, turned to the possibilities of the press, thus involving in his historic destiny the small figure of the city's second printer, John Peter Zenger.

\section{Zenger and His Lawyers}

Much telling over a quarter-millenium, almost entirely based on the Brief Narrative Alexander wrote and Zenger published after all was over, ${ }^{29}$ has made this part of the story familiar: how Cosby and DeLancey tried twice unsuccessfully to have Zenger indicted by the Grand Jury for seditious libel; how Cosby and his Attorney-General proceeded at last by information; how Smith and Alexander were disbarred, and how Hamilton saved the day and the cause of freedom. All this is known, and most of it happened.

But the Brief Narrative of the Case and Trial of John Peter Zenger was just that, and not everything that happened was part of the narrative of the case and the trial, as James Alexander saw it. A darker, more hidden thing also happened before the trial, in the winter of 1734, and we cannot understand the events of the ' 30 s without it, for all that it forms no part of the Brief Narrative. It happened in February, at James Alexander's house, during a dinner party. Perhaps William Smith, Sr. was there that night. Whether he was or not, his son, writing his History at the other end of a tumultuous time, had talked to many who were, Alexander not least. Let him tell it:

At the parting of some company from Mr. Alexander's, late in the evening of the 1st February, an incendiary letter was picked up in the hall. It had been shoved under the outer door, and was instantly pronounced by Mr. Alexander to be the handwriting of Mr. Harison, then a member of the Council. It was in these words:

29. James Alexander's A Brief Narrative of the Case and Trial of John Peter Zenger, Printer of the New York Weekly Journal was first printed by Zenger himself in 1736, and was reprinted fifteen times before the end of the eighteenth century, see Katz, supra note 6, at 37, becoming, as one historian wrote, "the most famous publication issued in America before the 'Farmer's Letters.' " Charles R. Hildeburn, Sketches of Printers and Printing in Colonial New York 25-26 (New York, Dodd, Mead \& Company 1895). For this information, as for so much else about the Brief Narrative, and the Zenger Case, I and everyone else remain forever indebted to the pathbreaking edition of Stanley Katz, for the John Harvard Library, of 1963. See generally Brief Narrative, supra note 6. 
To Mr. Alexander, I am one who formerly was accounted a gentleman, but am now reduced to poverty, and have no victuals to eat; and knowing you to be of a generous temper, desire you would comply with my request, which is, to let me have ten pistoles, to supply my necessaries and carry me to my native country. This is a bold request, but I desire you would comply with it or you and your family shall feel the effects of my displeasure. Unless you let me have them, I'll destroy you and your family by a stratagem which I have contrived. If that don't take the desired effect, I swear by God to poison all your tribe so surely, that you shan't know the perpetrator of the tragedy. I beg for God's sake that you would let me have the money, and hinder me from committing such a black deed. I know you can spare it, so desire you would let me have it. Saturday night, about 7 o'clock. Leave it by the cellar door wrapped up in a rag, and about an hour after I will come and take it. Put it on the ground just where I put the stick. If you don't leave it, I advise you not to drink your beer nor eat your bread if you value your life and healths, for by my soul, I will do what I've mentioned. If I find any watch to guard me in taking of it, I'll desist and not take it, but follow my intended scheme, and hinder you from acting any more on the stage of life. If you comply, I'll never molest you more; but if not, I'll hazard my life in destroying yours, and continue what I am.

From the neglect to disguise the hand, which Mr. Smith, Mr. Hamilton, Mr. Lurting the Mayor, all pronounced to be Mr. Harison's, it was conjectured that his design was to provoke a criminal prosecution, establish the precedent of convicting on the proof of a similtude of hands, and then, by counterfeiting the writing of one of the demagogues of the day, to bring him to the gallows, while the Governor's friends were to escape by pardon.

It was therefore with great earnestness that $\mathrm{Mr}$. Alexander, under the influence of that suspicion, when called before the grand jury, contended against their finding an indictment only upon such evidence, and with caution and reserve that he mentioned Mr. Harison's name, as the grand jurors themselves afterwards certified. They contented themselves with an address to the Governor, acquainting him that they could not discover the author, being able to have the evidence no higher than a resemblance between the letter and his writing: that lest a presentment or indictment by them upon such evidence, should prove a trap to ensnare some innocent person upon the oath they had taken, they durst not accuse any individual. They besought him, nevertheless, to issue a proclamation, with a promise of reward, for detecting the author of the villainy.

This matter was laid before the Council, and referred to Messrs. Harison, Van Horn, Kennedy, Delancey, Courtlandt, Lane, and Horsmanden, who, as a committee, proceeded to make the necessary enquiries preparatory to a report. As Mr. 
Alexander and Mr. Smith, who were summoned to attend there, refused to appear, while Harison, the suspected author, was of the committee, and Mr. Alexander, a member of the Board, left out, they proceeded only upon the testimony of Mr. Hamilton and Mr. Lurting; and though they advised a proclamation, offering fifty pounds for a discovery, yet they reported it as their opinion, that Mr. Harison was entirely innocent of the infamous piece of villainy laid to his charge, that he was incapable of being guilty of so foul a deed, and that the letter was a most wicked, scandalous, and infamous counterfeit and forgery, calculated by some artful, malicious, and evil-minded persons, to traduce and vilify the character of an honorable member of his Majesty's Council of this province, and thereby render him odious and infamous to mankind.

Whether the Governor was let into the design of the author of the letter, was never discovered, though some stress was laid upon words dropped by a man intimate in the family, who, coming home in his cups late in the evening shortly before the letter was found, said a scheme was executed to hang Alexander and Smith, and Mrs. Cosby frequently and without reserve had declared that it was her highest wish to see them on a gallows at the fort gate.

Harison was generally suspected, in spite of the testimonial of the Council, of which he made all the use in his power in an exculpatory address to the city Corporation whose Recorder he then was, suggesting that Mr. Alexander and Mr. Smith had forged the letter to ruin him. ${ }^{30}$

So the old times had begun again, and politics in New York was a game played for the highest stake of all, with the loser to dangle at the end of a rope. Or had they? Did Harison conspire, with or without Cosby's concurrence, to entrap and destroy his enemies? Did Cosby mean, as his amiable lady, sister of an Earl, suggested-that Smith and Alexander would end by being framed to the gallows? To our ear, the scheme sounds rather strained, the mechanism too indirect, the risks too high. And we shall never know. We can see the record of the Council, and the calling of the Grand Jury that considered indicting Harison, but there is no document anywhere that can tell us whether or not the suspicions to which Smith gave voice in his History were justified. But whether or not Harison's plot happened, we can be sure the suspicion happened, though the story of the Zenger Case has almost always been told without it. This was not a tale that James Alexander would have cared to tell in 1736, through Zenger's press, with relatives of both Cosby and Harison still alive. And whatever the truth may have been-the truth that we will never know-it must be kept in mind in telling the story of the case and trial of John Peter Zenger, and the larger events that surrounded it, that the lawyers who defended him thought they were playing the game not

30. 2 W. Smith, Jr., supra note 1 , at 8-10. 
just for the freedom of the poor insignificant printer, or the triumph at the Common Council elections, or the control of the Provincial courts, or the future of free speech, but for their lives.

The winter of 1734 became spring, and while Zenger's press hummed along, dispensing the Morrisites' electoral propaganda, the focus of the lawyers' activities shifted back to the issue of the equitable jurisdiction of the Supreme Court sitting in Exchequer. Now the legislature was the forum for debate; the political ferment of the preceding fall had resulted in calls for legislation to establish the courts, their jurisdictions, and their fee schedules, "for preserving the liberties and properties of the people from arbitrary encroachments." ${ }^{31}$ In June, William Smith, Sr. appeared before the Assembly to present the constitutional argument upon which the exceptions in the Van Dam case had been based. He renewed the claim that no equitable jurisdiction could be established without the consent of the legislature, since none could be established in England without the consent of Parliament. This was a carefully limited argument, which stopped short of raising the most explosive issue-the status of the Supreme Court itself. Five days later the argument on the other side was presented, not by Attorney-General Richard Bradley, but by Joseph Murray, another of the small coterie of busy and well-respected lawyers in practice in New York. A political advisor to the Governor, Murray should have spoken first, but was unprepared at the time of the hearing. Or perhaps he simply wanted the benefit of the last word. Murray chose interesting ground for his argument. The Assembly should not pass any legislation establishing the basic common-law and equitable jurisdictions, he argued, because the passage of such legislation might imply that the provincials lacked the preexisting English rights to the benefit of the common-law courts. If the courts existed because all Englishmen, including British North Americans, possessed them as of right, then legislation establishing them might be dangerous precedent-how many other inherent English rights might it then be argued New Yorkers did not possess?

This argument reflected Murray's adroitness. The Morrisites had adopted for their campaign the slogan of the Pulteney opposition at home: "King George, Liberty, and Law." Murray provided a justification for the Governor's chosen result that made his position seem that of the defender of traditional English liberties under law. The goal was to avoid legislation that Cosby would be required by his instructions to veto, in the teeth of the electoral propaganda of his opposition. But in the tail of his argument Murray had a sting for his client: since it was poor constitutional theory to pass legislation in New York that seemed to suggest New Yorkers had fewer rights than Englishmen, New Yorkers should limit themselves to the legislation Parliament itself had passed. Murray recommended legislation establishing that judges in New York be commis- 
sioned to sit during good behavior, rather than at the pleasure of the Governor. Murray was not defending the propriety of the dismissal of Lewis Morris, though he was arguing that it was legitimate without legislation. But Cosby's instructions, like those of every other Royal Governor, prohibited commissioning judges to sit during good behavior. If the legislature did as Murray suggested, the Governor would still be faced with a politically explosive situation, and from this one Murray had no intention of rescuing him.

One wonders if Cosby, as he read the printed versions of the lawyers' arguments before the legislature, understood the full significance of Murray's speech. ${ }^{32}$ The New York Bar, a tiny group of lawyers depending upon political privilege rather than professional organization to secure their livelihoods, was politically divided. Cosby had his legal machinery on the Bench and at the Bar, as the Morrisites had theirs, at least until the dismissal of the old Chief. But Murray's address to the Assembly should have served notice that there were limits to the political divisions at the Bar. On some points, of which judicial independence was one, the Bar was beginning to respond in its own interest, as a unit, regardless of individual adherence to political faction. This solidarity was incipient rather than complete, and one could hardly blame Cosby for ignoring its implications. But a process that had begun before his Governorship would give further evidence of its presence before all was over. The nascent solidarity and professionalism of the Bar would prove to be the key to the Zenger Case, and the engine of Cosby's defeat in the larger game afoot.

The early history of the legal profession in New York is a story of uncoordinated individual enterprise. ${ }^{33}$ In the great mixture of nations that was New York in the seventeenth century, many passed through the Province who made their livings pleading and papering, with divers results. If it is hard to substantiate one Governor's irate complaint that those practicing in the courts of the province at the turn of the century included a dancing master, a glover, and a man sentenced to death at home for blasphemy, ${ }^{34}$ the motley disorganization of the cadre of practitioners was nonetheless its predominant descriptive feature.

32. The legislature, being as William Smith, Jr. rather slyly said, "confounded by the long arguments they had heard ... requested copies for the press." 2 id. at 13. No doubt a few also perceived that both arguments, and not just the one of their partisan counsel, would make splendid political fodder in circles to which the risque ballads and satiric advertisements in the New York Weekly Journal were not particularly directed. In any event, thanks to the press of John Peter Zenger, we can see William Smith, Jr., Mr. Smith's Opinion Humbly Offered to the General Assembly of the Colony of New-York (1734), and Joseph Murray, Mr. Murray's Opinion Relating to the Courts of Justice in the Colony of New-York (1734).

33. For an interpretive account of the development of the New York Bar, see Moglen, supra note 12, at 209-44. Invaluable basic materials are collected in Paul M. Hamlin, Legal Education in Colonial New York (1939).

34. See Letter from Earl of Bellomont to the Lords of Trade (Dec. 15, 1698), in 4 N.Y. Colonial Documents, supra note 25, at 441-42. 
But there were men of parts present at all times. Some came as appointees of the Crown, remained beyond their tenure, and went home, or, like Roger Mompesson, gave their careers to the provincial system. And, as the first two decades of the eighteenth century passed, the flow of younger, capable immigrants-seeking to begin and carry on their careers in New York-increased: let James Alexander, fleeing Scotland from the consequences of his Jacobite sentiments in ' 15 , stand for them. Then too, the sons of the wealthy in New York increasingly found education in North America best finished off with an expensive but elevating period eating their dinners in the Inns of Court-the Livingstons as early as 1706, others, such as William Smith, Sr., Yale '19 and Gray's Inn, later. And then there was James DeLancey, at his ease in the center of the Supreme Court Bench, with his family's money behind a Cambridge Degree and the Inner Temple-the pinnacle of Provincial arrivisme.

Still, as the elite of the profession coalesced before 1725, it was individual political influence, not professional organization, that magnified and sustained power and profit. Office, whether as City Recorder or Judge in Admiralty, was stability of both income and influence, and the key to office was political clout. ${ }^{35}$ No single incident more fully reflects this stage in the development of the profession than that of the Montgomerie Charter and the Mayor's Court Bar. During the Administration of Silent Jack, though hardly at his personal instance, the government of the City was thoroughly refounded by the issuance of a new Charter. ${ }^{36}$ Among the institutions of government to be rechartered was the Mayor's Court-the most important court of first instance for much of the commercial and other general litigation of the seaport. The Charter gave to eight named lawyers-James Alexander, Joseph Murray, John Chambers, William Smith, George Lurting, William Jamison, Richard Nicolls, and Abraham Lodge-the exclusive right to practice in that court. ${ }^{37}$

Yet even as the Montgomerie Charter showed the full flowering of the use of the political system, rather than private organization, to secure the benefits of professional monopoly, the same younger generation of lawyers was taking the first effective steps towards the organization of the Bar. In 1729, their monopoly in the Mayor's Court soon to be secured by legislation, a group of the same usual suspects-William Smith, Joseph Murray, James Alexander, and John Chambers-joined together, with two additional adherents, in the first anticompetitive private association of the Bar. Their agreement, as might be supposed, was directed against

35. For a compressed version of the exemplary and piquant post-Zenger story of Admiralty business and the Morris family, see Moglen, supra note 12, at 141 \& n.84.

36. The single best analysis of the Montgomerie Charter in its larger context is found in Hendrik Hartog, Public Property and Private Power: The Corporation of the City of New York in American Law, 1730-1830 (1983).

37. See The Mongomerie Charter of the City of New York, Jan. 15, 1730, reprinted in 2 N.Y. Colonial Laws, supra note 12, at 575, 625. 
newer, allegedly less capable practitioners who might commit the ungentlemanly infraction of getting some business. Their effective agreement was:

That when any practitioner who has obtained his Licence since the last day of June 1725 is employed in any Cause We or either of Us shall not directly or indirectly be concerned on that Side, by advice or otherwise and if any such practitioner or his Client or any other person shall apply to either of us to be concerned [we] shall absolutely refuse to be concern'd . . . \& immediately send word thereof to the rest of us. ${ }^{38}$

The details of the 1729 agreement are of little moment; we do not know whether the principle of noncooperation was ever employed, or what its effects were. What matters is that the key lawyers of the Province, though separated by partisan animosities that were to be seen in the events of the 1730s, were tentatively learning to see their collegial identity as professionals alongside their partisan affiliations in the individual search for power and preferment. Alexander, Chambers, Murray, and Smithseated around a table negotiating the interests of the Bar (at least their segment of it)-were laying the foundations that, despite their divisions in 1734-1735, would keep the explosion of partisan rancor from destroying the courts, the legal system, and their fortunes.

So, when Joseph Murray gave his recommendation to the legislature in June of 1734, he spoke simultaneously for Cosby and judicial independence, and the partisan war went on. The Morrisites prevailed in the Common Council elections in September, electing virtually the entire anti-Cosby slate. Chief Justice DeLancey made two attempts to convince the Grand Jury to indict Zenger for seditious libel. In October, after the elections, he told the Grand Jury: "Sometimes heavy, halfwitted men get a knack of rhyming, but it is time to break them of it, when they grow abusive, insolent, and mischievous with it." ${ }^{39}$ Behind Zenger lay the real writer whom Zenger would be pressured, after conviction, to give up. No doubt James Alexander appreciated the Chief Justice's compliments.

The duel went on, and in November Lewis Morris begged formal leave of absence from his seat in the Assembly, to visit his property in New Jersey. From there, bearing careful instructions drawn up in consultation with Alexander, Smith, and the others of his party, he took ship for England. Perhaps this, like so many other colonial political crises, would be resolved by the metropolitan deus ex machina, and Lewis Morris was the man best suited to the task of turning the crank on the machine. ${ }^{40} \mathrm{But}$, with Morris' withdrawal, the tactical control and danger of the situation passed to Smith and Alexander. If their fears from February turned out

38. Agreement Made Among the Lawyers, July 28, 1729, John Jay Papers, Reel 2, No. 16V (New York Historical Society, Manuscripts Department).

39. 2 W. Smith, Jr., supra note 1, at 14-15.

40. For the separate story of Morris' mission, and its equivocal results, see Katz, supra note 22 , at $91-132$. 
to be well-founded, anything might happen before Morris returned. Zenger was but an outwork to be defended, and yet a crucial one, for it was there that the legal firepower of the Governor was evidently to be directed.

Even as Morris was making his arrangements to depart, and consulting with his inner circle on the plan of his negotiations, the Governor stormed the outwork. Abandoning hope of securing Zenger's indictment by the Grand Jury, which would have given him some political cover for the act, the Governor in Council at the beginning of November simply ordered Zenger's arrest. Though still a member of the Council, James Alexander was of course not invited to be present when the deed was done. On Saturday, November 23 (was Morris already dropping with the tide toward the Atlantic?), Smith and Alexander appeared to seek Zenger's admission to bail. Though counsel argued that the Bill of Rights of 1689 declared that excessive bail should not be required, and offered Zenger's testimony that all his nonexempt property amounted to less than $£ 40$, DeLancey set bail at $£ 400$, and Zenger remained in jail. The Weekly Journal missed but one issue, to be sure, for there were others to run the press, and the literary skill of James Alexander had hardly run out-besides, there was still much Trenchard \& Gordon that had not yet been reprinted. ${ }^{41}$ In January 1735, the Attorney-General exhibited an information against Zenger for seditious libel, thus aggravating another constitutional sore spot in the Province, ${ }^{42}$ and the matter moved back to the Supreme Court, for resolution of the legal issues before trial.

On April 15, 1735, on a piece of parchment a few inches square, Smith and Alexander made the move that changed the shape of the game. "Exceptions," it said, "humbly offered by John Peter Zenger to the Power of the Honourable James DeLancey, Esq; to judge in this Cause." There followed a challenge to the commission of Philipse as well. In both, Smith and Alexander repeated the same arguments made in challenging the commissions in the Van Dam case. But where the claim with respect to the Exchequer sitting had been that there was no legislative authorization for an equitable jurisdiction in the Supreme Court, Smith and Alexander now argued that-in addition to the absence of good behavior tenure and evidence of advice and consent by the Council-the

41. See generally John Trenchard \& Thomas Gordon, Cato's Letters; Or, Essays on Liberty, Civil and Religious, And other important Subjects (reproduced and reissued in 1969) (New York, Russell \& Russell 3d ed. 1733). On the influence of radical Whig theory in colonial America, see Bernard Bailyn, The Ideological Origins of the American Revolution 33-54 (1971).

42. The issue of prerogative prosecution played a similar, though less consistently inflammatory, role in the legal and political life of the province to the problem of prerogative courts. This problem too had been on the tapis in the Assembly after 1727, but the legal strategy of Zenger's counsel did not call for expatiation upon this particular evil. For a general consideration of the issue through the provincial period, see Moglen, supra note 12 , at $185-89$. 
commission gave power to Judges of the Supreme Court to have jurisdiction both of claims cognizable by King's Bench and of Common Pleas, contrary to common law and without legislative authorization. ${ }^{43}$

Though the legal effect of the arguments made for Zenger was the same as those made for Van Dam, the political consequences of the provocation were infinitely more explosive. In Van Dam's case, Smith and Alexander had presented to a friendly Chief Justice a collusive argument to deadlock an institution without regular business, whose very convening was a piece of political jugglery by the Governor. The new exceptions were presented to a hostile Bench, for the asserted purpose of disqualifying the Judges of the highest and most important court of the Province. Nothing about the exceptions was particular to Zenger's case-they could be made and insisted upon in every piece of Supreme Court litigation. The rejection of the exceptions (and there was plainly no other course) would hand the Morrisites a permanent trump in the propaganda war against the gubernatorial party. Smith and Alexander were signaling their willingness to draw Governor and Assembly into the irresistible-force-meets-immoveable-object of provincial constitutional politics. To gain both time and the credibility of menace, DeLancey told counsel to consider the consequences of their action, and adjourned the matter for a day.

Perhaps DeLancey consulted with the Governor overnight; though what he did next was staggeringly unwise, it has the mark not only of his youthful indiscretion but also of Cosby's more calculated madness. When Smith appeared for argument on April 16, DeLancey announced that he would hear no argument, and said:

You thought to have gained a great deal of popularity and applause by opposing this Court as you did the Court of the Exchequer, but you have brought it to that point that either we must go from the bench or you from the bar, and therefore we exclude you and Mr. Alexander from the bar.

At this point DeLancey handed the clerk a minute already written out, stating that:

James Alexander, Esq. and William Smith, attorneys of this Court, having presumed (notwithstanding they were forewarmed by the Court of their DISPLEASURE if they should do it) to sign, and having actually signed and put into Court, exceptions in the name of John Peter Zenger; thereby denying the legality of the judges their commissions; though in the usual form and the being of this Supreme Court. It is therefore ordered that for the said contempt, the said James Alexander and William Smith be excluded from any farther practice in this Court, and that their names be struck out of the roll of attorneys of this Court. ${ }^{44}$

43. The exceptions were reprinted in the Brief Narrative, supra note 6 , at 50-52. 44. Id. at 54 . 
A little legal sparring then ensued. Alexander, also present, asserted that the objections were to the commissions of the judges, not to the being of the court. The court could exist after all, he pointed out, even if all the commissions of the sitting judges were invalid. DeLancey seems to have accepted the truth of this assertion. Smith then engaged DeLancey in colloquy as to whether the exceptions had been rejected or overruled, the primary intention of which-since procedurally all that was at stake was whether counsel had to move their lost exceptions into the recordwas to drive DeLancey to confess that he didn't know the difference.

Alexander's point was more significant. By apparently limiting the scope of the exception to the commission of the judges, counsel were reducing the likelihood that the exceptions could be found contumacious in a technical sense, denying the authority of the court. Technically, Alexander was no doubt correct. But the political bearing of the exceptions was as broad as DeLancey claimed. For if the exceptions were good in law, no Judges of the Supreme Court could be commissioned with a broad common-law jurisdiction until the legislature or Parliament authorized the court, and that led directly to the black hole.

If the political significance of the Morrisite maneuver was incendiary, that of the Governor and Chief Justice was even more so. Having demonstrated his willingness to displace his political opposition from the Bench, the Governor now maintained his right, at displeasure, to remove them from the Bar. The disbarment of Alexander and Smith, as they were soon to maintain before the Assembly, was an attempt to take political control of the entire legal system.

In the long view, the rash decision of the Chief Justice and his master may not have disconcerted Alexander and Smith completely. To be deprived of practice in the Supreme Court was a financial blow, but their statutory piece of the Mayor's Court business was proof against gubernatorial interference so long as the Mayor and Common Council were Morrisite, and they were hardly likely to starve. The spectacle of partisan expropriation (and it was in this light that Alexander and Smith would present the Chief Justice's action to the Assembly) raised the specter of the bad old days, but nothing more fully vindicated the Morrisite claim to be the party of "King George, Liberty, and Law" than the attempt to make the whole legal system the tame creature of the Governor. The tactical situation was nonetheless grave. The Zenger trial would now be an effectual test of the Governor's power to control the legal process, and Zenger's counsel were now at least formally hors de combat. Of those remaining within the circle of credible counsel, Murray-perhaps the most accomplished lawyer in the Province-was completely identified with the Governor, and hence impossible. Zenger prayed the assistance of counsel, and DeLancey made the only other reasonable appointment-John Chambers.

Though the appointment was not overtly biased, it plainly left Smith and Alexander unhappy. Chambers was a placeman of the Governor, 
having been made by him Recorder of the City. Not by any means wellaffected to the Morrisites, Chambers was evidently seen by Zenger's counsel as a sop to convention, whose job it would be to put up the show of a decent defense. William Smith, Jr. no doubt repeated the dismissive judgment of his father and Alexander, echoing down the years, when he said of Chambers that he was "more distinguished for a knack at haranguing a jury than his erudition in the law." 45 This, ironically, would prove to be a fair description of the great Andrew Hamilton, upon whom the hopes of the Morrisites would eventually come to rest. The younger Smith again no doubt reports the judgments of Zenger's counsel when he says that Chambers "had no inclination" to represent Zenger. For a man busy building his practice and depending on political favor for his office, the whole business probably seemed a package of borrowed trouble. Dismissively, and again probably reporting the contemporary judgment of the other lawyers, Smith says that Chambers "abandoned the mode of defence chalked out by [Zenger's] first advocates, and taking ground safer to himself, pleaded the general issue for his client and obtained a rule for a struck jury." 46

But here, understandably, the historian's judgment is out. The defense offered by Smith and Alexander was no defense at all, simply a political provocation designed to make use of Zenger's case to dig a pit for the Chief Justice and Governor. No one had supposed for a moment that it would succeed, and it in no wise improved Zenger's legal position. Chambers saw as well as anyone else where the interest of his client laythe petit jury selected would determine the outcome of the case. Lewis Morris wasn't Chambers' client, nor Smith and Alexander, nor the freedom of the press. Zenger was the client, and against inclination, against interest, perhaps against safety, Chambers went solidly about the business of getting him off.

The request for a struck jury was the critical motion, for it enabled Chambers to have some role in selecting the jury panel, rather than leaving that matter to the Sheriff. There had been monkey business enough by Sheriffs in the long war, and there would be more to come. DeLancey took the motion for a struck jury under advisement, and set trial for Monday, August 4. The date was April 16, and nothing else would happen, formally, until the end of July.

When did Smith and Alexander decide to retain Hamilton and supersede Chambers as trial counsel? No paper gives a hint, and we shall probably never know. Certainly Chambers was not informed, and went about the business of preparing for his trial under the assumption that he would have to do the job. His trial brief survives, and is included in Stanley Katz's edition of Alexander's narrative. ${ }^{47}$ From it we can see that

45. 2 W. Smith, Jr., supra note 1 , at 19 .

46. 2 id.

47. See Brief Narrative, supra note 6, at Appendix B. 
he planned to seek a nullifying verdict, but on a far narrower ground than that intended by Alexander, who was-even as the summer beganpreparing the submission he intended to speak through Hamilton's mouth. Where Alexander wanted to call witnesses to prove the truth of various charges made by the Weekly Journal against Cosby, Chambers planned to ask the jury to find that the satires were too indefinite in their object to make good the Attorney-General's innuendos. Not in itself a plausible argument, for everybody knew at whom the Weekly Journal directed its pasquinade, it was a technically adequate peg upon which a jury could safely find a factual basis for an acquittal. The critical thing was to get a sympathetic jury. And for that, even Alexander seems to have considered poor plodding Chambers a sufficient beast of burden. He had no intention of exposing his dark horse to daylight for that quotidian purpose.

On July 29, the Court convened to consider Chambers' motion for a struck jury. The motion was granted, and the jury was to be picked on the evening of that day. The procedure for selecting a struck jury was commonplace, for they were frequently used, particularly in commercial cases where the parties had an interest in knowledgeable jurors. The Sheriff randomly chose forty-eight names from the list of freeholders qualified to serve, and each side struck out as many as twelve names. From the remaining twenty-four the Sheriff rounded up twelve to serve. But when the lawyers gathered on the evening of the 29th, Cosby's Sheriff presented a list of forty-eight names preselected, not drawn on the spot from the Freeholders' Book. On that list were Cosbyite municipal officers defeated by Morrisite candidates at the last elections and a number of tradesmen who did business with the Governor's household. Much now depended on the composition of this jury, and it is hard not to reach the conclusion that the Governor intended a cheat.

But Chambers wouldn't go along. Had he done so, shamming his defense even the slightest bit, the whole war would have ended differently. No doubt he had much reason to let it by. At least for the foreseeable future, there could be no doubt on which side his bread was buttered. But he was a member of a profession, and he would have to practice with his adversaries forever. And even if Cosby removed him to the Bench-as a future Governor would do-and he remained there until his death - as he very nearly did-he felt himself to be a member of a guild, with rules larger than the interest of any one man. Probably he didn't even hesitate; in that moment, Cosby's whole edifice collapsed. Chambers called an end to the proceedings, and the following morning moved DeLancey for a rule directing the Sheriff to produce the Freeholders' Book as usual. Let us give the Chief Justice credit; perhaps he was shocked. At any rate, the motion could hardly be denied-the conventions for selecting a struck jury were entirely clear, and no professional lawyer or judge could have articulated a reason for disregarding themand a jury was fairly picked. 
The trial opened on Monday, August 4. The jury was seated, and again Chambers found there had been skulduggery. The order of seating had been changed from the order on the original list; someone wanted a different foreman. Chambers was on his feet, with the original panel in hand, and the Chief Justice, with magisterial severity, ordered the oversight corrected. 48 The Attorney-General opened his case and then, apparently rather suddenly, Andrew Hamilton "who had been secretly engaged, presented himself on the day of trial as the champion of liberty." 49 When did Chambers find out? Surely not in the courtroom, though the masterminds of the whole matter left him there to deal with the opening festivities, and he had prepared a full brief for the trial. What did he think when Hamilton began the process of twisting his jury's tail?

From this instant, John Chambers disappears, in silence, from the Zenger case and from the whole story. He died in 1764, having been Justice of the Supreme Court from 1751 to 1763 . He left behind a fine library, the inventory of which belies William Smith, Jr.'s implication that he was not a man of learning. His practice papers have largely survived, and if they reveal a man of sometimes careless method, they show nonetheless an effective and well-trained lawyer. But nothing he left us contains a further word on the Zenger episode and no one, then or later, busied himself about giving Chambers credit. Everyone has known, for 250 years, what Hamilton did that day-how he defied the judge, cajoled the jury, changed the law. We all know that by his eloquence he acquitted Zenger, like Daniel Webster in Jabez Stone's New Hampshire kitchen, arguing against the Devil. ${ }^{50}$ To hear some people tell it, he changed the world. And he certainly deserved the party they threw him, and all the speeches, and the big send-off the next morning, with cannonades and cheering, even if he did leave without the freedom of the city or a gold box. Compared to all that, John Chambers didn't do anything very much. Perhaps not, but he did enough.

\section{Death and Transfiguration}

Zenger's acquittal in August 1735 was a major strategic break in the war between Cosby and the Morrisite opposition. The action of the jury brought to an end the Governor's dangerous experiment with political control of the legal system. As a test of the maturity, the degree of "settlement" of the legal system, the whole episode showed that the institutions were robust enough to resist the determined assault of a Governor prepared to pack the Bench and winnow the Bar to turn the legal system into a device for muzzling his opposition. But the key was not the courts themselves, for so far as that went Cosby and DeLancey had nearly proved

48. See id. at 57-58.

49. 2 W. Smith, Jr., supra note 1 , at 19.

50. See Stephen Vincent Benet, The Devil and Daniel Webster (1937). 
the opposite proposition. Two other communal organizations had made the difference-the jury and the Bar. That juries provided a constitutional check on executive power was not a lesson any English-speaking person needed the Zenger case to teach-that was why English people loved juries so deeply, and why British North Americans were willing to respond with organized civil violence when jury trial was interfered with by an assertedly sovereign Parliament in the 1760s and 1770s. But the other lesson of the Zenger case was that a professionalized Bar was not so pliable in the hands of Administration. Partisan division there might be-Murray and Chambers were no friends to the Morrisites. But there were lines a self-consciously coherent Bar would not cross, and "Liberty and Law" was a slogan that meant something even to lawyers not marching under the banner.

Nonetheless, when the cheering stopped the war was hardly over. Alexander and Smith were still disbarred, there was still an empty chair on the Supreme Court Bench, and no one was bothering to invite James Alexander and Rip Van Dam to Council meetings. In November 1735, Cosby formally suspended Van Dam from the Council. Until the outcome of Morris' mission to London could be known, contest would continue, in the legislature and the courts.

The fall of 1735 was largely consumed by fighting on another front. Smith and Alexander presented The Complaint of James Alexander and William Smith to the Committee of the General Assembly of the Colony of New-York, $\mathcal{E}^{2} c \ldots,,^{51}$ a recapitulation of Zenger's right to challenge the Judges' commissions and their own grievance against arbitrary disbarment. On the latter point, Alexander and Smith penned a pleasant comparison of the illegal expropriation of a man's land and chattels with the arbitrary deprivation of their livelihood. Along the way, they offered a description of the professional world of which they formed a part that speaks eloquently of the self-confident nature of the provincial legal profession:

These Judges might, with as much Justice, have burnt all our Law Books, as to have deprived us of the Use of them; and have destroyed our Deeds, and taken away our Houses and our Lands, as to have taken away the Liberty of Exercising our Employments, which were as dearly bought as any Thing we enjoy. We came not to them but by the Way of an expensive Study of several Languages, Arts and Sciences; our Abilities for them were the Purchase of many Years hard and costly Labor; we were duly admitted to our Practice, we ever used it with Fidelity and a good Conscience, and with what Acceptance, and Esteem of our Country, we doubt not but that a Thousand Witnesses can declare.52

The political purpose of this recitation was another partisan expedition on the old strategic lines-attempting to embroil the Assembly in a feud

51. Printed by one John Peter Zenger, New York, 1736.

52. Id. at 15. 
with the Governor over the regulation of the courts-this time by encouraging the legislature to attempt discipline of the Judges, or at least to authorize the maintenance of a suit against them for damages. ${ }^{53}$ But the words were truer than the intentions. This very pride in craft, and sense of responsibility to the community for the protection of the law, was the force against which Cosby's attempt to control the system had shattered. As a community, the lawyers of New York had reached an important stage in their political development. For all the agile cynicism of the Morrisite propaganda for law and liberty, the crowd was cheering something real. The willingness of lawyers to defend the subject's liberty under law, if necessary at the hazard of their lives, their fortunes, and their sacred honor, was now an important force in North America. William Cosby would not be the last Imperial Executive who would be able to read that message without his spectacles.

In the race between the mills of God and the bureaucracy of the British Empire, the mills won. By the late winter of $1735 / 36$, it was common knowledge that the Governor was dying, and on March 10, 1736 the eternal part of William Cosby departed New York forever, while what was left was buried within the walls of the fort at the tip of Manhattan Island, largely unlamented. In London, Morris was unavailingly trying to interest the Privy Council in granting him a hearing on the state of the government at New York. ${ }^{54}$ Cosby's death put the dice back into the box for another throw, and the whole long story of contest with edge tools seemed to be resolved on a note of anticlimax.

But that's not how it ever was in New York. Once again, the New Yorkers demonstrated that a dead Governor could be more dangerous than a live one, even if he was William Cosby. The interim Governor, by the old rule, was the senior member of the Council. But was that Rip Van Dam, suspended-illegally, as he claimed-by Cosby, or was it Cosby's senior advisor, George Clarke? Behind Van Dam, that grand old man nearing his seventy-sixth birthday, stood James Alexander-the fat was in the fire once again. Both sides began appointing office-holders, petitions to the Privy Council flew from all sides, and everyone looked forward to September 29, 1736, when the new year's officers would take power, wondering which side's people would be in charge when the smoke cleared. It didn't, and by mid-October the Province seemed to be drifting toward civil war. Only the sudden arrival of Royal Instructions naming Clarke Lieutenant-Governor brought the whole dangerous farce to a sudden and complete halt. But that's another story. ${ }^{55}$

53. See id, at 18.

54. See Katz, supra note 22, at 124-25.

55. Well told by both William Smith, Jr., see 2 W. Smith, Jr., supra note 1, at 24-28, and Stanley Katz, see Katz, supra note 22, at 133-39. 


\section{The Motroes on the BoX}

Let us return to Michaelmas 1735, the first day of New York's administrative year, weeks after the end of the Zenger trial. A committee of three Aldermen, appointed September 16, report their draft of the freedom of the City, to be presented to Andrew Hamilton

under A Gratefull sense of the Remarkable service done to the Inhabitants of this City and County ... by his learned and Generous defence of the Rights of Mankind and the Liberty of the Press in the case of John Peter Zenger ... which he Chearfully undertook under great Indisposition of body and Generously performed Refusing any ffee or Reward. . . .

And we do further Report that sundry of the Members of this Corporation and Gentlemen of this City have Voluntarily Contributed sufficient for A Gold Box of five Ounces and A half for Inclosing the seal of the Said Freedom, upon the Lid of which we are of Opinion Should be Engraved the Arms of the City of New York. ${ }^{56}$

The Common Council so ordered, and "Mr. Alderman Bayard going to Philadelphia and offering to be the bearer of the said freedom to Mr. Hamilton," that was ordered too. Thus, sometime in the fall of 1735 Stephen Bayard-son of that Nicholas Bayard who was imprisoned by Leisler, demanded Leisler's execution, and was himself convicted of treason and sentenced to death by a kangaroo court in 1702-privately presented to Andrew Hamilton the freedom of the City of New York and a small gold box.

It's not surprising that William Smith, Jr. - working in the dispiriting seclusion of Livingston Manor, without his books and papers, dreading the outcome of the war that had now begun between his King and his community-remembered the box as being presented to Andrew Hamilton the day after the trial. Perhaps Smith was even present at the summer morning's festivities as Hamilton departed for Philadelphia. But for him, as for James Alexander, seeking an image on which to end his Brief Narrative of the whole business, it was the box that stood out, and even more than the box itself, the mottoes engraved on it.

Smith could not have transcribed the mottoes into his History from a copy of Alexander's Narrative, because the narrative gives the correct chronology of the gift of the box, and even includes the Common Council orders. Smith was much too careful, and too respectful of Alexander, to have preferred his childhood recollection to Alexander's written words. He remembered the mottoes independently, as everybody did who was concerned to know the history of the episode of Cosby, Morris, Alexander, Smith, Hamilton, and John Peter Zenger. They were the center of the story.

56. 4 Minutes of the Common Council of the City of New York 1675-1776, at 277-78 (1905). 
"Demersae legis-time facta libertas-haec tandem emergunt": Though the laws are sunk, and liberty trembles at the deed, yet shall they rise again. "Non nummis, virtute paratur": Not by money, but by virtue gained. "Ita cuique eveniat ut de respublica meruit": Thus let each receive what he has deserved of the republic. It was right to begin with Cicero, ${ }^{57}$ for no one more succinctly expressed both in his life and in his words, to these educated Englishmen of the eighteenth century, the classical virtues of the lawyer-zealous for the client and the laws, fearless of tyranny, above all taint or corruption. Not by money, to be sure, for lawyering was not merely a trade-the virtue of lawyers was the pursuit of justice. In the end, as Alexander and Smith had said in their complaint to the Assembly, the lawyers justified themselves by the approval of the community whose freedoms they preserved.

The mottoes on the box were about lawyers, expressing the aspirations of a profession feeling the growth of political support for what it did. By cleaving to the cause of liberty, lawyers would deserve well of the Republic. This was the message resonating in the space between 1735 and 1777 , even before there was a republic that could pay to the virtue of lawyers the honor it deserved. ${ }^{58}$ For William Smith, Jr., who did not think that Andrew Hamilton had with his "fraudful dexterity" accomplished much, there was one thing he had accomplished: by "the severity of his invectives upon the Governor and his adherents ... the jury missing the true issue before them, as if they were triers of their rulers rather than Zenger, pronounced the criminal innocent because they believed them to be guilty."59 In the power of the law to try the rulers, even if not in the case of Zenger himself, lay the virtue of the lawyers; if Smith saw little to celebrate in the particular outcome of the Zenger trial, even for him that lesson was sterling gold.

What happened to the box? Like so much else, it seems to have vanished altogether. Surely Hamilton himself did not melt it down. Five

57. See Marcus Tullius Cicero, De Officiis, bk. II, ch. VII, para. 24, at 190 (Walter Miller trans., G.P. Putnam's Sons 1928) ("Quamvis enim sint demersae leges alicuius opibus, quamvis timefacta libertas, emergunt tamen haec aliquando aut iudiciis tacitis aut occulis de honore suffragiis"- "For let the laws be never so much overborne by some one individual's power, let the spirit of freedom be never so intimidated, still sooner or later they assert themselves either through unvoiced public sentiment, or through secret ballots disposing of some high office of state." (emphasis added)); see also Marcus Tullius Cicero, Philippics, bk. II, ch. XLVI, para. 119, at 182 (Walter Miller trans., G.P. Putnam's Sons 1926) ("Duo modo haec opto, unum, ut moriens populum Romanum liberum relinquam (hoc mihi maius ab dis immortalibus dari nihil potest), alterum, ut ita cuique eventiat, ut de re publica quisque mereatur"- "These two things only I pray for; one, that in my death I may leave the Roman people free-than this no greater gift can be given me by the immortal Gods-the other, that each man's fortune may be according to his deserts toward the State." (emphasis added)).

58. But the new Republic did. For a study of the culturally dominant role of the legal profession in post-Revolutionary America, see Robert A. Ferguson, Law and Letters in American Culture (1984).

59. 2 W. Smith, Jr., supra note 1, at 20. 
and one-half troy ounces-a small box. Perhaps-like so many other members of the colonial elite, a snuff-taker-he put it on his table and kept his snuff in it. That would be fitting, for he scattered much dust in the eyes of the jury in 1735, and his dust has kept the historians sneezing for most of the last 250 years. Yet now that it has settled, we can see the story a trifle more clearly. Perhaps we can perceive both larger contours and smaller details than Hamilton and Alexander, with all their eloquence, intended. Behind the fog of partisan war we can descry both the changes in the culture of a profession and the simple workaday integrity of a good and honest lawyer, who happened to be John Chambers rather than Andrew Hamilton or James Alexander. And we can see once again what the history of the law, both true and untrue, so often teaches-that it matters very much indeed what lawyers do, and how much they believe in the virtue of the law. ${ }^{60}$

60. This story of the stories of the Zenger trial has three heroes: John Chambers, who did what he could for justice; William Smith, Jr., who told well a story often ignored or misunderstood; and Stanley Katz, whose painstaking and insightful scholarship at every turn made it possible to understand. To each of them my gold box is dedicated. 